\title{
PRINSIP-PRINSIP KEADILAN HUKUM DALAM ASAS LEGALITAS HUKUM PIDANA ISLAM
}

\author{
(Justice Principles in The Principle of Legality of Islamic Criminal Law)
}

\author{
Moh Khasan \\ Fakultas Syariah dan Hukum Universitas Islam Negeri Walisongo \\ JI. Walisongo 3-5 Semarang \\ Email: moh.khasansmg@yahoo.com
}

Naskah diterima:15 Maret 2017; revisi: 12 April 2017; disetujui: 17 April 2017

\begin{abstract}
Abstrak
Asas legalitas memiliki kedudukan yang sangat fundamental dan menjadi asas penting dalam hukum pidana. Asas Legalitas yang berlaku saat ini memiliki keterbatasan dalam memperjuangkan nilai-nilai keadilan hukum sehingga memunculkan beberapa kritik dan wacana pembaharuan dari para ahli hukum. Salah satu wacana yang hendak dikaji adalah penggunaan Asas Legalitas Hukum Pidana Islam sebagai bahan untuk melakukan rekonstruksi substansi hukum yang ada saat ini. Melalui metode yuridis normatif akan digali secara komprehensif prinsip-prinsip keadilan hukum yang terkandung dalam Asas Legalitas Hukum Pidana Islam dan kemungkinan penerapannya dalam hukum pidana di Indonesia. Temuan penelitian ini adalah bahwa secara normatif, Asas Legalitas Hukum Pidana Islam memiliki kedekatan dengan norma-norma agama karena bersumber dari Nas. Oleh karenanya, asas-asas legalitas yang dirumuskan sangat kental makna teologis dan spiritualitas. Asas Legalitas Hukum Pidana Islam memiliki karakteristik fleksibilitas dalam penerapan Asas-Asas Legalitasnya karena dukungan klasifikasi tindak pidana yang efisien. Asas legalitas Hukum Pidana Islam memiliki kontribusi signifikan dalam pembaharuan hukum pidana di Indonesia yaitu kontribusi yang bersifat ideologis, berupa hukum pidana dengan filosofi Ketuhanan Yang Maha Esa, dan kontribusi yang bersifat yuridis, berupa karakter hukum pidana yang sederhana, efisien, responsif, progresif dan seimbang.
\end{abstract}

Kata Kunci: asas legalitas, hukum pidana Islam, sistem hukum, keadilan

\begin{abstract}
The principle of legality has a fundamental position and has become an important principle in criminal law. The current principle of legality has limitations in the struggle for justice which then raises some criticism and ideas of reconstruction. One of the ideas is the use of principle of legality of the Islamic Criminal Law as a component to improve the current legal substance. Through the normative juridical method this study will explore comprehensively the principles of legal justice contained in the principle of legality of the Islamic Criminal Law and the possibility of its application in Indonesia criminal law. The findings of this research are: normatively, the principle of legality of Islamic Criminal Law has a close relationship with the religion norms because it comes from "Nas". Therefore, the principles of legality that were formulated has very strong theological and spiritual meaning. The principle of legality of Islamic Criminal Law has the flexibility characteristic in its principle of legality appliance because of the efficient classification of criminal acts. The principle of legality of Islamic Criminal Law has a significant contribution in the reconstruction of criminal law in Indonesia that is an ideological contribution, in the form of criminal law with the believe in one supreme God philosophy, and the juridical contribution, in the form of criminal law with, a simple, efficient, responsive, progressive and balanced character.
\end{abstract}

Keywords: principle of legality, Islamic criminal law, system of law, justice 


\section{A. Pendahuluan}

Salah satu asas pokok dalam hukum pidana adalah asas legalitas (principle of legality). Asas legalitas memiliki kedudukan yang sangat fundamental dan oleh karenanya menjadi salah satu asas yang paling penting dalam hukum pidana. Asas ini antara lain mengatur tentang apa dan bagaimana sebuah tindakan atau perbuatan dapat dikategorikan sebagai tindak pidana dan didasarkan atas dalil apa. Diperkenalkannya asas legalitas dalam ilmu hukum pada awalnya berfungsi secara normatif untuk membuat standar atas perilaku seseorang sehingga dapat dikategorikan sebagai sebuah tindak pidana (delik) ataukah tidak. Namun pada perkembangannya, asas legalitas juga digunakan sebagai alat untuk menetapkan kebijakan hukum secara sewenang-wenang oleh penguasa. Inilah di antara wujud problem absolutisme asas legalitas. ${ }^{1}$

Hukum positif di Indonesia mengenal asas legalitas dalam KUHP pasal 1 ayat (1), bahwa setiap perbuatan yang disebut sebagai perbuatan/tindak pidana harus dirumuskan dalam undang-undang yang diadakan terlebih dahulu yang menetapkan dalam rumusan yang jelas tentang perbuatan-perbuatan dimaksud. Sebagai konsekuensinya, sebuah perbuatan yang menurut pandangan masyarakat dianggap sebagai perbuatan tercela karena melanggar nilai-nilai hukum yang hidup dalam masyarakat tidak dapat dipidana karena tidak diatur secara tertulis dalam undangundang. ${ }^{2}$ Dengan bahasa yang lain, Deni Setyo Bagus Yuherawan menyatakan bahwa sangat tidak masuk akal membebaskan orang yang telah melakukan kejahatan hanya karena kejahatan itu tidak dilarang oleh undangundang pidana. Hal ini karena setiap perilaku kejahatan harus ada pertanggungjawaban pidananya. $^{3}$ Pertanggungjawaban tersebut hakikatnya merupakan upaya untuk mengembalikan keadaan menjadi baik seperti semula dan mewujudkan keadilan. Oleh karenanya sekecil apapun kejahatan harus ada pertanggungjawabannya.

Kondisi Asas Legalitas beserta segala konsekuensinya tersebut, telah merangsang munculnya beberapa kritik dan wacana pembaharuan dari para ahli hukum. Salah seorang dari mereka, Deni Setyo Bagus, menganggap sudah waktunya menumbuhkembangkan ide dekonstruktif terhadap Asas Legalitas dengan paradigma yang baru. la berargumentasi bahwa Asas Legalitas telah memperlakukan pelaku dan korban secara tidak proporsional. Asas legalitas

\footnotetext{
Secara substansial, Asas Legalitas hanya melaksanakan dua fungsi, yaitu: 1) fungsi perlindungan, melindungi warga negara dari kesewenang-wenangan kekuasaan penguasa dan kewenangan hakim; dan 2) fungsi pembatasan, membatasi kekuasaan penguasa dan/atau kewenangan hakim. Fungsi perlindungan hanya ditujukan untuk kepentingan pelaku. Pelaku tidak akan dituntut selama perbuatan mereka bukanlah mala prohibita (bertentangan dengan undang-undang). Fungsi pembatasan juga hanya ditujukan untuk kepentingan pelaku, karena penguasa tidak boleh menuntut pelaku yang melakukan crimina extra ordinaria (perbuatan pidana yang belum atau tidak dilarang oleh undang-undang pidana), walaupun menimbulkan kerugian yang luar biasa bagi korban. Deni Setyo menyebut kondisi seperti ini sebagai keterbatasan Asas Legalitas. Lebih jauh baca: Deni Setyo Bagus Yuherawan, Dekonstruksi Asas Legalitas Hukum Pidana; Sejarah Asas Legalitas dan gagasan Pembaharuan Filosofis Hukum Pidana, (Malang: Setara Press, 2014), hlm. 6-8 dan 81-91.

2 I Dewa Made Suartha, "Pergeseran Asas Legalitas Formal Ke Formal dan Material dalam Pembaharuan Hukum Pidana Nasional", Jurnal Yustisia 19, (2015), hlm. 139-140

3 Deni Setyo Bagus Yuherawan, Dekonstruksi Asas Legalitas Hukum Pidana; Sejarah Asas Legalitas dan gagasan Pembaharuan Filosofis Hukum Pidana, (Malang: Setara Press, 2014), hlm. 7.
} 
hanya mengakomodasi kepentingan serta menjunjung tinggi hak asasi pelaku dengan mengorbankan kepentingan dan hak asasi korban, yang sering kali berjumlah jauh lebih banyak dari pelaku. ${ }^{4}$

Asas legalitas sering dilihat sebagai ketentuan yang secara absolut dianggap benar sehingga secara formil pasti telah mewakili rasa keadilan masyarakat. Oleh sebab itu maka ketentuan-ketentuan dalam undang-undang harus ditegakkan bagaimanapun caranya dan mesti diperlakukan sebagai representasi dari nilai-nilai keadilan. ${ }^{5}$ Konsekuensi dari pola pikir dan paradigma seperti ini tentu saja adalah persepsi yang berlebihan dengan menganggap bahwa hukum adalah undang-undang dan undang-undang sama dengan hukum. Paradigma formalistik dalam melihat hukum ini telah berakibat semakin sulitnya menemukan keadilan sejati. Yang ada adalah keadilan yang formal, sempit dan kaku, yakni keadilan yang tidak mewakili semua hak dan kepentingan, baik hak korban, pelaku, negara, dan masyarakat. ${ }^{6}$

Oleh karena itu muncul berbagai wacana untuk menggali Asas Legalitas yang dapat mewakili norma hukum yang hidup dan berkembang dalam masyarakat. Dalam rangka memperkuat fungsi Asas Legalitas untuk mewujudkan keadilan hukum, menurut Sri Rahayu, bahwa penentuan tindak pidana harus didasarkan tidak hanya pada Asas Legalitas Formal melainkan juga pada Asas Legalitas Material. ${ }^{7}$ Senada dengan Rahayu, I Dewa Made Suartha berpendapat bahwa salah satu upaya pembaharuan hukum pidana dapat dilakukan dengan cara berpindah dari paradigma Asas

Ibid., hlm. 7.

5 Di antara gagasan-gagasan besar yang diperjuangkan dalam RUU-KUHP adalah tentang rekonstruksi Asas Legalitas, yaitu: a) menempatkan Asas Legalitas tidak lagi sebagai kebenaran absolut; b) menerobos, bahkan melemahkan Asas Legalitas, dan c) Memunculkan Asas Legalitas baru yakni Asas Legalitas Materiil. Dasar pemikiran dari gagasan tersebut adalah walaupun masih mengakui derajat ke-asas-an Asas Legalitas, penyusun RUU-KUHP bertekad memposisikan hukum yang hidup/hukum yang tidak tertulis sebagai sumber hukum pidana. Arah pemikiran ini sudah jelas, yaitu untuk menciptakan hukum pidana dan sistem peradilan pidana yang lebih berkeadilan, terutama lebih memperhatikan kepentingan korban, serta tekad untuk menuntut dan memidana setiap kejahatan. Baca: Deni Setyo Bagus Yuherawan, Ibid., hlm. 261.

6 Beberapa kasus hukum di Indonesia disinyalir masih menunjukkan adanya kesenjangan antara hukum dan keadilan. Seperti kasus "pencurian biji kakao" nenek Minah di Banyumas tahun 2009 (http://regional.kompas. com/read/2009/11/19/07410723/duh....tiga.buah.kakao.menyeret.minah.ke.meja.hijau...(diakses $1 \quad$ April 2017); Lihat: Soetandyo WIgnyosoebroto, "Nenek Minah Tak Curi Cokelat", Opini Kompas, 15 Februari 2010; Kasus "biji randu" Manisih dkk di Batang tahun 2009 (http://nasional.kompas.com/read/2009/12/10/10563340/ Hukum.di.Balik.Sekarung.Buah.Randu (diakses 1 April 2017); Kasus "pencurian sandal jepit" di Palu Sulawesi Tengah tahun 2012 (http://nasional.kompas.com/read/2012/01/06/09445281/Kejamnya.Keadilan.Sandal. Jepit. (Diakses 1 April 2017); Kasus "pencurian semangka" Basar dan Kholil di Kediri tahun 2009. (http:// nasional.kompas.com/read/2009/11/30/23470786/semangka.darwati.antar.kholil.masuk.penjara. (diakses 1 April 2017); Kasus "pencurian kayu jati" nenek Asyani di Situbondo tahun 2014. (http://regional.kompas.com/ $\mathrm{read} / 2015 / 04 / 24 / 17200701 /$ Asyani.Teriakkan.Ketidakadilan. (diakses 1 April 2017).

7 Asas ini menggariskan bahwa dasar untuk menentukan patut tidaknya suatu perbuatan dianggap bersifat melawan hukum atau sebagai perbuatan pidana adalah nilai-nilai yang hidup dalam masyarakat (living law) atau hukum tidak tertulis. Legalitas material akan menjadi sebuah refleksi dari keinginan dan rasa keadilan masyarakat. Asas ini memberikan kepastian hukum secara substansiil atau secara materiil. Hal ini berbeda dengan asas Legalitas formil yang memberikan kepastian hukum secara formil. Lebih lanjut baca: Tongat, DasarDasar Hukum Pidana Indonesia dalam Perspektif Pembaharuan, (Malang: UMM Press, 2012), hlm. 53-54. Baca juga: Sri Rahayu, "Implikasi Asas Legalitas dalam Penegakan Hukum dan Keadilan", Jurnal Inovatif Vol. VII No. 3, (2014), hlm. 1-11. 
Legalitas formal kepada Asas Legalitas formal dan material. ${ }^{8}$

Pemikiran yang sama disampaikan Barda Nawawi Arif mengkritisi ketentuan Asas Legalitas hukum pidana sebagaimana tercantum dalam KUHP pasal 1 ayat (1). Menurutnya, dengan adanya ketentuan pasal 1 ayat (1) KUHP, seolaholah hukum pidana tidak tertulis yang hidup dalam masyarakat sengaja ditidurkan atau dimatikan. Ditidurkannya hukum pidana tidak tertulis pada jaman penjajahan bisa dimaklumi, karena memang sesuai dengan politik hukum Belanda saat itu. Namun akan sangat dirasakan janggal apabila kebijakan itu diteruskan setelah kemerdekaan. Dengan adanya asas legalitas formal, hukum tidak tertulis/hukum yang hidup menjadi tidak tergali dan terungkap secara utuh ke permukaan, khususnya dalam praktek peradilan pidana. ${ }^{9}$

Kritik terhadap Asas Legalitas juga disampaikan dalam perspektif ontologis maupun aksiologis, yakni bahwa Asas Legalitas dianggap memiliki keterbatasan-keterbatasan. Di antara keterbatasan itu adalah: 1) Asas Legalitas hanya dapat bermakna jika ditopang oleh undang-undang yang baik (good penal law). Sebaliknya, Asas Legalitas menjadi tidak bermakna jika ditopang oleh undang-undang pidana yang tidak baik (bad penal laws); 2) Asas Legalitas tidak memiliki daya jangkau untuk menuntut 'crimina extra ordinaria' (tindak pidana luar biasa), walaupun perbuatan tersebut menimbulkan kerugian luar biasa bagi korban dan/atau masyarakat; 3) Adanya keterbatasan daya jangkau terhadap 'crimina extra ordinaria', Asas Legalitas sama sekali tidak melakukan fungsi perlindungan terhadap kepentingan korban dan/atau masyarakat. ${ }^{10}$

Penelitian kecil ini sebenarnya juga memiliki keprihatinan yang sama dengan para peneliti sebelumnya. Kesamaan pemikiran yang ingin dibangun adalah bahwa perbaikan sistem hukum di negara ini memang harus diawali dengan membangun paradigma substansi hukum. Dengan mereformasi substansi hukum, maka potensi untuk memperbaiki struktur hukum dan budaya hukum menjadi sistematis dan lebih terarah. Di antara substansi hukum yang perlu mendapat perhatian adalah Asas Legalitas hukum. Perbedaannya, jika peneliti sebelumnya menggunakan bahan yang sama, yaitu Asas Legalitas hukum pidana positif (KUHP), penelitian ini mencoba menawarkan gambaran Asas Legalitas Hukum Pidana Islam sebagai bahan untuk melakukan rekonstruksi.

Dipilihnya tema tersebut dilandasi oleh keprihatinan yang sama sebagaimana disampaikan oleh Barda Nawawi bahwa hukum yang hidup dalam masyarakat perlu digali dan diungkap secara utuh ke permukaan dalam rangka melengkapi keberadaan Asas Legalitas formal yang telah berlaku. Keberadaan Asas Legalitas yang lebih komprehensif karena mewakili unsur-unsur hukum yang hidup dalam masyarakat diharapkan dapat mewujudkan keadilan hukum yang sesungguhnya.

Oleh karena itu maka beberapa pokok pikiran yang akan didiskusikan dalam penelitian ini terkait dengan pengertian dan makna Asas Legalitas menurut Hukum Pidana Islam dan 
penerapan Asas Legalitas Hukum Pidana Islam, serta kontribusi Asas Legalitas Hukum Pidana Islam dalam pembaharuan hukum pidana di Indonesia.

\section{B. Metode Penelitian}

Penelitian ini bersifat yuridis normatif, yaitu dengan melakukan kajian terhadap norma-norma hukum, khususnya peraturan perundang-undangan tertentu atau hukum tertulis. ${ }^{11}$ Penelitian normatif adalah penelitian yang dilakukan dengan cara meneliti bahan pustaka atau data sekunder belaka. Pemikiran normatif didasarkan pada penelitian yang mencakup: 1) asas-asas hukum; 2) sistematik hukum; 3) taraf sinkronisasi vertikal dan horisontal; 4) perbandingan hukum; 5) sejarah hukum. Penelitian ini juga disebut penelitian hukum non doktrinal. Pembuktian dilakukan melalui proses deduksi, bertolak dari sebuah proposisi umum yang sudah tak terbantahkan kebenarannya (self evident, given). Proposisi mayor ini harus dicari sumber-sumbernya yang formal, ialah hukum dan perundang-undangan dan/atau doktrin-doktrinnya. ${ }^{12}$

Adapun hukum tertulis yang dimaksudkan dalam penelitian ini adalah norma-norma hukum syariah yang terkandung dalam alQur'an dan Hadis serta bahan-bahan sekunder tentang Asas Legalitas dalam Hukum Islam.

\section{Pembahasan}

Berdasarkan pokok-pokok permasalahan yang dikemukakan dalam pendahuluan, maka pembahasan dalam tulisan ini akan difokuskan pada tiga topik, yaitu: pengertian dan makna Asas Legalitas Hukum Pidana Islam, penerapan Asas Legalitas Hukum Pidana Islam, dan Kontribusi Asas Legalitas Hukum Pidana Islam dalam pembaharuan hukum pidana di Indonesia.

\section{Pengertian dan Makna Asas Legalitas}

Kata asas berasal dari bahasa arab asasun yang berarti dasar atau prinsip, sedangkan kata "legalitas" berasal dari bahasa latin yaitu lex yang berarti undang-undang, atau dari kata jadian legalis yang berarti sah atau sesuai dengan ketentuan undang-undang. Dengan demikian arti legalitas adalah keabsahan menurut undang-undang. ${ }^{13}$ Asas legalitas berkaitan dengan ketentuan yang menyatakan bahwa tidak ada pelanggaran dan tidak ada hukuman sebelum ada undang-undang yang mengaturnya.

Menurut Moeljatno, asas legalitas (Principle of legality) adalah asas yang menentukan bahwa tidak ada perbuatan yang dilarang dan diancam dengan pidana jika tidak ditentukan terlebih dahulu dalam perundang-undangan. Dalam bahasa latin disebut sebagai nullum delictum nulla poena sine praevia lege. (tidak ada delik, tidak ada pidana tanpa peraturan lebih dahulu). ${ }^{14}$ Menurutnya, dari formulasi Asas Legalitas tersebut setidaknya dikandung tiga pengertian: 1) tidak ada perbuatan yang dilarang dan diancam dengan pidana kalau hal itu terlebih dahulu belum dinyatakan dalam suatu

11 Lebih jauh lihat Soerjono Soekanto dan Sri Mamudji, Peranan dan Penggunaan Perpustakaan di Dalam Penelitian Hukum, (Jakarta: Pusat Dokumentasi Hukum Fakultas Hukum Universitas Indonesia, 1979), hlm. 15.

12 Soetandyo Wignjosoebroto, "Ragam-Ragam Penelitian Hukum", dalam S. Irianto dan Sidharta (ed.), Metode Penelitian Hukum; Konstelasi dan Refleksi, (Jakarta: Yayasan Pustaka Obor Indonesia, 2011), hlm. 131-132.

13 Subekti dan Tjitrosudibyo, Kamus Hukum, (Jakarta: Pradnya Paramita, 1969), hlm. 63.

14 Moeljatno, Asas-Asas Hukum Pidana, (Jakarta: Rineka Cipta, 2000), hlm.23. 
aturan undang-undang; 2) untuk menentukan adanya perbuatan pidana tidak boleh digunakan analogi; 3) Aturan-aturan hukum pidana tidak boleh berlaku surut. ${ }^{15}$ Sedangkan Peter Mahmud Marzuki mendefinisikannya sebagai tiada seorang pun dapat dipidana karena melakukan suatu perbuatan jika tidak ada aturan undang-undang yang mengatur sebelum perbuatan dilakukan. ${ }^{16}$ Kedua pengertian di atas memiliki substansi yang sama yaitu perbuatan seseorang pada dasarnya tidak dapat dijerat hukum apabila tidak ada undang-undang yang mengaturnya sebelum perbuatan tersebut dilakukan. Sementara itu, secara lebih tegas menurut Wirjono Prodjodikoro, bahasa latin Asas Legalitas yang berbunyi nullum delictum, nulla puna sine praevia lege punali diartikan tiada kejahatan, tiada hukuman pidana tanpa undang-undang hukum pidana terlebih dahulu. ${ }^{17}$

Para ahli hukum pidana pada dasarnya sepakat dengan adanya 3 (tiga) makna dalam asas legalitas, yaitu: a) tidak ada perbuatan yang dilarang dan diancam dengan pidana kalau hal itu belum dinyatakan terlebih dahulu dalam suatu undang-undang; b) untuk menentukan adanya perbuatan pidana tidak boleh digunakan analogi (qiyas); c) aturan-aturan hukum pidana tidak berlaku surut. ${ }^{18}$ Tiga makna asas legalitas tersebut mengakibatkan adanya dua implikasi, yaitu: 1) larangan menggunakan analogi (prinsip non analogi); dan 2) keharusan menggunakan undang-undang pidana yang berlaku pada saat perbuatan dilakukan. Artinya, dilarang memberlakukan undang-undang pidana secara retroaktif (prinsip non-retroaktif). ${ }^{19}$

Di Indonesia, Asas Legalitas diwujudkan dalam aturan hukum yaitu pasal 1 ayat (1) Kitab Undang-Undang Hukum Pidana (KUHP) yang menyatakan: "Tiada suatu perbuatan dapat dipidana kecuali atas kekuatan aturan pidana dalam perundang-undangan yang telah ada, sebelum perbuatan dilakukan" Ketentuan tentang "aturan pidana dalam undang-undang yang telah ada" dalam pasal 1 ayat (1) KUHP ini memiliki pengertian bahwa harus ada empat unsur penting dalam hukum pidana, yaitu: 1) kualifikasi perbuatan pidana; 2) undang-undang pidana yang harus diberlakukan; 3) sumber hukum pidana; dan 4) sistem hukum pidana. ${ }^{20}$

Dalam Hukum Pidana Islam, prinsip Asas Legalitas ditemukan dalam beberapa aturan pokok dalam ajaran Islam. Pertama, kaidah yang menyatakan: Sebelum ada Nas (ketentuan), tidak ada hukum bagi perbuatan orang-orang yang berakal sehat"21 Artinya, perbuatan seseorang yang cakap (bekwaam) tidak mungkin dikatakan dilarang selama belum ada ketentuan (Nas) yang melarangnya, dan ia memiliki kebebasan untuk melakukan perbuatan itu atau meninggalkannya, sehingga ada Nas yang melarangnya. ${ }^{22}$ Aturan pokok yang kedua adalah kaidah yang menyatakan: "Pada dasarnya semua perkara dan semua perbuatan

\footnotetext{
Ibid, hlm. 25.

Peter Mahmud Marzuki, Pengantar Ilmu Hukum, (Jakarta: Kencana Prenada Group, 2008), hlm. 215.

Wirjono Prodjodikoro, Asas-asas Hukum Pidana Di Indonesia, (Bandung: Refika Aditama, 2003), hlm. 43.

Moeljatno, Op. Cit, hlm. 25.

Deni Setyo Bagus Yuherawan, Loc. Cit., hlm. 5.

Deni Setyo Bagus Yuherawan, Loc. Cit., hlm. 2-3.

Kaidah fikih tersebut berbunyi: La hukma li af'al al-'uqala' qabla wurud al-nash. Lihat dalam: Ahmad D. Hanafi, Asas-Asas Hukum Pidana Islam, (Jakarta: Bulan Bintang, 1993), hlm. 58. Baca juga: Ahsin Sakho Muhammad, et.al (eds), Ensiklopedi Hukum Pidana Islam, (Jakarta: PT. Kharisma Ilmu, 2007), hlm. 134-135.

22 Ahmad D. Hanafi, Ibid.; Ahsin Sakho Muhammad, et.al (eds), Ibid.
} 
diperbolehkan"23 Artinya, semua perbuatan dan semua sikap tidak berbuat dibolehkan dengan kebolehan asli, yakni bukan kebolehan yang dinyatakan oleh Nas. Jadi selama belum ada Nas yang melarang, maka tidak ada tuntutan terhadap semua perbuatan dan semua sikap tidak berbuat. ${ }^{24}$ Aturan pokok yang ketiga adalah kaidah yang menyatakan: "Orang yang dapat diberi pembebanan (taklif) hanya orang yang memiliki kesanggupan untuk memahami dalildalil pembebanan dan untuk mengerjakannya, dan pekerjaan yang dibebankan hanyalah pekerjaan yang mungkin dilaksanakan dan disanggupi serta diketahui pula sehingga dapat mendorong dirinya untuk memperbuatnya". ${ }^{25}$ Ketiga aturan pokok itulah yang diyakini sebagai elemen fundamental keberadaan Asas Legalitas dalam hukum Pidana Islam.

Asas Legalitas dalam Hukum Pidana Islam juga didasarkan pada Al-Qur'an surat alBaqarah: 286, surat al-An'am: 19, surat al-Isra':
15, dan surat al-Qashash: $59,{ }^{26}$ Semua ayat tersebut memiliki substansi yang sama, yaitu selama tidak ada ketentuan hukum yang berisi perintah atau larangan maka tidak ada hukum bagi seseorang yang melakukan perbuatan tertentu.

\section{Penerapan Asas Legalitas Hukum Pidana Islam}

Tindak pidana (jarimah) dalam Hukum Pidana Islam diklasifikasikan menjadi tiga, yaitu hudud, qisas-diyat, dan ta'zir. ${ }^{27}$ Jarimah hudud adalah tindak pidana yang diancam dengan hukuman hudud, yaitu hukuman yang telah ditentukan jenis dan jumlahnya dan menjadi hak Tuhan. Jarimah Hudud terdiri atas tujuh macam, yaitu: zina, qadzaf (menuduh zina), meminum minuman keras, mencuri, hirabah (mengganggu keamanan/merampok), murtad, memberontak. ${ }^{28}$ Jarimah qisas-diyat adalah tindak pidana yang diancam hukuman qisas dan

23 Kaidah tersebut adalah: Al-Ashl fi al-asyya' wa al-af'al al-ibahatu. Lihat: Ahmad Hanafi, Ibid.

24 Ahmad D. Hanafi, Ibid.; Ahsin Sakho Muhammad, et.al (eds), Ibid.

25 Ahmad D. Hanafi, Ibid., hlm. 59; Ahsin Sakho Muhammad, et.al (eds), Ibid., hlm. 135.

26 Suratal-Baqarah 286 menyatakan: "Allah tidak membebani seseorang melainkan sesuai dengan kesanggupannya"; Surat al-An'am: 19 menyatakan: "Dan al-Qur'an ini diwahyukan kepadaku supaya dengannya aku memberi peringatan kepadamu dan kepada orang-orang yang sampai al-Qur'an (kepadanya)"; Surat Al-Isra': 15 menyatakan bahwa: "Kami tidak akan menyiksa sebelum Kami mengutus seorang Rasul"; Surat Al-Qasas: 59 menyatakan: "Dan Allah tidak akan menghancurkan penduduk suatu negeri sebelum diutusnya Rasul di tengahtengah mereka untuk membacakan ayat-ayat Kami.." Lihat: Al-Qur'am dan Terjemahnya, (Jakarta: Yayasan Penyelenggara dan Penterjemah/Pentafsir Al-Qur'an, 1990), hlm. 72, 189, 426, \& 619.

27 Klasifikasi tersebut didasarkan atas kategori berat ringannya hukuman. Selengkapnya lihat: Ahsin Sakho Muhammad, et.al (eds), hl. 99-101; Abdul Qadir 'Audah, al-Tasyri' al-Jina'i al-Islami, (Beirut: Muassasah alRisalah, 1994), hlm. 78-81; Ahmad D. Hanafi, Asas-Asas Hukum Pidana Islam, hlm. 6-9; Kategori klasifikasi yang lain, lihat: Moh Khasan, "Reformulasi Teori Hukuman Tindak Pidana Korupsi Menurut Hukum Pidana Islam", (Laporan Penelitian Individual IAIN Walisongo Semarang, 2011), hlm. 23-36.

28 Hukuman hudud yaitu hukuman yang ditetapkan atas tindak pidana hudud. Hukuman hudud bermacam-macam sesuai dengan jenis tindak pidananya. Hukuman bagi perbuatan zina terdiri atas dera, pengasingan, dan rajam. Hukuman tindak pidana memfitnah orang lain berbuat zina (qadzaf) berupa dera delapan puluh kali dan tidak diterima persaksian pelakunya. Hukuman minum minuman keras berupa dera empat puluh dan delapan puluh kali. Hukuman tindak pidana pencurian adalah potong tangan (berdasarkan ketentuan yang sangat ketat). Hukuman tindak pidana gangguan keamanan (hirabah) terdiri atas hukuman mati, potong tangan dan kaki, serta pengasingan. Hukuman pemberontakan dan murtad berupa hukuman mati. Selengkapnya, baca: Ahmad D. Hanafi, Asas-Asas Hukum Pidana Islam, hlm. 263-279; Abdul Qadir 'Audah, al-Tasyri' al-Jina'i al-Islami, hlm. 634662; Rudolph Peters, Crime and Punishment in Islamic Law, (Cambridge: Cambridge University Press, 2005), hlm. 53-65. 
diyat. Tindak pidana ini terdiri atas lima macam, yaitu: pembunuhan sengaja, pembunuhan menyerupai sengaja, pembunuhan tersalah, penganiayaan sengaja, dan penganiayaan tersalah. ${ }^{29}$ Jarimah ta'zir adalah tindak pidana yang tidak termasuk dalam kategori hudud maupun qisas-diyat. Tindak pidana Ta'zir diancam dengan satu atau beberapa hukuman ta'zir, yaitu hukuman yang prinsipnya berupa pendidikan dan tidak membinasakan. Jenis tindak pidana ini tidak ditentukan jumlahnya, kecuali sebagian, seperti perbuatan-perbuatan yang selamanya akan tetap dianggap sebagai tindak pidana, misalnya: riba, khianat, memaki orang, menyuap, dll. Penentuan jenis tindak pidana ta'zir diserahkan kepada penguasa. ${ }^{30}$

Terkait dengan miskonsepsi umum bahwa hakim memiliki kekuasaan bebas dalam menangani pelanggaran ta'zir, Abdul Qadir 'Audah, sebagaimana dikutip Kamali, menunjukkan bahwa syariah memberikan batasan-batasan tertentu terkait kekuasaan seorang hakim. Maka salah jika dikatakan bahwa hakim memiliki kebebasan wewenang dalam menentukan tindak pidana maupun hukumannya. Hakim pertama-tama, harus menentukan apakah suatu perilaku dianggap maksiat sesuai dengan teks syariat yang jelas. Pelanggarannya kemudian harus dibuktikan melalui bukti yang disyaratkan hukum. Hakim hanya memilih jenis hukuman yang telah divalidasi oleh syariat. ${ }^{31}$ Ketika menentukan hukuman untuk tindak pidana ta'zir, seorang hakim harus menentukan hukuman yang sah, dari sekedar peringatan sampai denda dan pemenjaraan, dan memutuskan apakah hukumannya akan ditangguhkan atau dijalankan dengan segera. Dengan kata lain, seorang hakim memiliki kewenangan diskresi dalam tindak pidana ta'zir, sebagaimana digambarkan oleh 'Audah sebagai sulthat al-ikhtiyar (kekuasaan untuk memilih) dan bukan sulthat al-tahakkum (kekuasaan untuk membuat hukum sekehendak hati). Menurut ketentuan hukum Islam, tidak ada hakim atau organ pemerintahan lainnya yang memiliki kekuasaan tanpa batas, termasuk dalam tindak pidana ta'zir. ${ }^{32}$

Klasifikasi tindak pidana dalam Hukum Pidana Islam tersebut sangat jelas didasarkan pada sistem hukum yang ingin dibangun oleh hukum Islam. Yaitu sistem yang mengutamakan kepatuhan kepada Nas (agama) dan prinsip-

29 Hukuman qisas adalah hukuman yang ditetapkan atas tindak pidana qisas, yaitu pembunuhan dan penganiayaan. Hukuman yang berasaskan balasan setimpal dengan perbuatannya, yaitu dengan pembunuhan jika seseorang membunuh secara sengaja dan penganiayaan jika seseorang menganiaya secara sengaja (kecuali jika dimaafkan oleh korban atau keluarga korban). Sedangkan diyat adalah hukuman pokok bagi pembunuhan dan penganiayaan semi-sengaja dan tidak sengaja. Diyat berupa memberikan harta kepada korban, bukan kepada perbendaharaan negara. Oleh karenanya dikenal juga sebagai ganti rugi, uang darah, restitusi, dan finansial compensation. Lihat dalam: Ahmad D. Hanafi, Asas-Asas Hukum Pidana Islam, hlm. 284-293; Rudolph Peters, Crime and Punishment in Islamic Law, hlm. 44-53. Abdul Qadir 'Audah, al-Tasyri' al-Jina'i al-Islami, hlm. 663-678.

30 Hukuman ta'zir adalah hukuman yang ditetapkan atas tindak pidana ta'zir. Yaitu berupa hukuman dengan karakteristik yang berbeda dari hudud dan qisas-diyat yang telah ditentukan oleh Nas. Menurut syariat, hukuman ta'zir bertujuan untuk memberikan pengajaran (ta'dib) dan tidak sampai membinasakan. Oleh karenanya jenis hukuman berat seperti pemotongan anggota badan dan penghilangan nyawa hanya dibolehkan sebagai pengecualian. Hukuman ta'zir terdiri atas berbagai macam, dari yang paling ringan sampai berat, seperti: peringatan, denda, dera, pengasingan, pengucilan, penjara, dan salib. Baca: Ahmad D. Hanafi, Asas-Asas Hukum Pidana Islam, hlm. 299-318; Abdul Qadir 'Audah, al-Tasyri' al-Jina'i al-Islami, hlm. 685-706.

31 Mohammad Hashim Kamali, Membumikan Syariah, (Bandung: Mizan, 2013), hlm. 250.

32 Mohammad Hashim Kamali, Op.Cit., hlm. 250. 
prinsip keadilan yang paripurna, mencakup keadilan bagi pelaku tindak pidana, keadilan bagi korban tindak pidana, dan keadilan bagi masyarakat dan negara. Pemikiran inilah yang selanjutnya memberikan warna dan karakteristik pada penerapan Asas legalitas Hukum Pidana Islam.

Penerapan Asas Legalitas pada jarimah hudud dilakukan dengan teliti dan cermat. Hal ini tergambar pada ayat-ayat al-Qur'an dan Hadis yang menjadi sumber Asas Legalitas tersebut. Pada jarimah zina, Asas Legalitas menyatakan: "Pezina perempuan dan pezina laki-laki, deralah masing-masing dari keduanya seratus kali.." (surat an-Nur: 2). Asas Legalitas qadzaf (menuduh zina) berbunyi: "Dan orang-orang yang menuduh perempuan-perempuan yang baik (berzina) dan mereka tidak mendatangkan empat orang saksi, maka deralah mereka delapan puluh kali, dan janganlah kamu terima kesaksian mereka untuk selama-lamanya.."(surat an-Nur: 4). Adapun Asas Legalitas pencurian adalah: "Adapun orang laki-laki maupun perempuan yang mencuri, potonglah tangan keduanya (sebagai) balasan atas perbuatan yang mereka lakukan dan sebagai siksaan dari Allah" (surat al-Maidah: 38). ${ }^{33}$

Penerapan Asas Legalitas jarimah qisasdiyat tidak berbeda jauh dengan hudud. Kekuasaan hakim pada jarimah ini sama dengan kekuasaan hakim pada hudud. Seorang hakim tidak memiliki kebebasan untuk memilih hukuman atau menentukan berat-ringannya hukuman. Bentuk hukuman telah ditentukan oleh Nas, sehingga hakim tinggal menetapkan saja apabila telah terbukti kesalahannya. Perbedaannya terletak pada larangan seorang hakim menjatuhkan hukuman qisas atau diyat bila ada pengampunan dari pihak korban. Asas Legalitas pembunuhan sengaja yaitu:"Janganlah kamu membunuh jiwa yang dimuliakan oleh Tuhan, kecuali dengan cara yang benar." (surat al-Isra: 33). Asas Legalitas penganiayaan yang dimaafkan yaitu: "Siapa yang menganiaya seorang Muslim dengan membunuhnya, maka baginya qisas, kecuali apabila wali korban memaafkannya" (Hadis). ${ }^{34}$

Penerapan Asas Legalitas dalam jarimah ta'zir berbeda dengan penerapan asas legalitas dalam jarimah hudud dan qishashdiyat. Penerapan Asas Legalitas pada jarimah ini diperlonggar sampai pada batas tertentu karena pertimbangan maslahat. Kelonggaran di sini terdapat pada hukumannya dan pada bentuk tindak pidananya. Abdul Qadir Audah membagi hukuman ta'zir menjadi tiga bagian: a) Hukuman ta'zir atas perbuatan maksiat; Yakni hukuman ta'zir diterapkan atas setiap perbuatan maksiat, yang tidak dikenakan had dan tidak pula kifarat, baik perbuatan maksiat tersebut menyinggung hak Allah maupun hak adami; b) Hukuman ta'zir dalam rangka mewujudkan kemaslahatan umum. Menurut kaidah umum yang berlaku selama ini dalam syari'at islam, hukuman ta'zir hanya dikenakan terhadap maksiat, yaitu perbuatan yang dilarang karena zat perbuatannya itu sendiri sebagai penyimpangan dari aturan pokok tersebut. c) Hukuman ta'zir atas perbuatan pelanggaran (mukhalafah). Pelanggaran (mukhalafah) adalah

33 Ahsin Sakho Muhammad, et.al (eds), Ensiklopedi, hlm. 137-141; Ahmad D. Hanafi, Asas-Asas Hukum Pidana Islam, hlm. 61-63.

34 Ahsin Sakho Muhammad, et.al (eds), Ensiklopedi, hlm. 141-144; Ahmad D. Hanafi, Asas-Asas Hukum Pidana Islam, hlm. 64-67. 
melakukan perbuatan makruh (yang dibenci) atau melakukan perbuatan mandub (sunnah). Untuk menjatuhkan ta'zir atas perbuatan mukhalafah, disyaratkan berulang-ulangnya perbuatan yang dapat dikenakan hukuman. Jadi, sebenarnya penjatuhan itu bukan karena perbuatannya itu sendiri melainkan karena berulang-ulang, sehingga perbuatan itu menjadi adat kebiasaan. ${ }^{35}$

Fleksibilitas penerapan Asas Legalitas Hukum Pidana Islam sesungguhnya merupakan konsekuensi logis dari klasifikasi tindak pidana yang dirumuskan. Hukum Pidana Islam membagi jarimah menjadi tiga jenis; yaitu jarimah hudud, jarimah qisas-diyat, dan jarimah ta'zir. Pengaturan atau formulasi tindak pidana seperti ini menjadi menarik karena beberapa hal; pertama, dalam hal jenis tindak pidana, manusia seakan menjadi pihak yang tidak memiliki otoritas untuk mengaturnya karena sebagian telah ditetapkan oleh alQur'an dan Hadis. Khususnya untuk tindak pidana hudud dan qisas-diyat, manusia hanya terima jadi apa yang telah diatur dalam Nas tersebut. Namun demikian sesungguhnya pernyataan tersebut tidaklah sepenuhnya benar. Pada sebagian ketentuan tentang tindak pidana qisas-diyat manusia diberikan otoritas dan hak yang sangat besar untuk mengatur, yakni dalam hal menentukan sanksi terhadap pelaku pembunuhan atau penganiayaan. Bahkan pada jenis tindak pidana ta'zir, manusia diberikan otoritas penuh untuk mengatur dan menentukan jenis tindak pidana dan juga sanksi hukumnya berdasarkan indikator-indikator perbuatan pidana yang telah disampaikan oleh Nas tersebut. ${ }^{36}$

Kedua, klasifikasi tindak pidana dalam Hukum Pidana Islam mengisyaratkan adanya perumusan jenis aturan hukum yang tegas, kaku, dan tanpa kompromi pada satu sisi, serta perumusan jenis aturan hukum yang longgar, lentur, dan fleksibel di sisi yang lain. Pada tindak pidana hudud dan qisas-diyat, harus dibuat ketentuan seperti jenis yang pertama, yaitu tegas, kaku, dan tanpa kompromi. Hal ini karena terkait dengan aspek kepastian hukum sebagaimana ketentuan Tuhan dalam Nas, dan oleh karenanya menjadi Hak Tuhan. Sementara pada tindak pidana ta'zir dan sanksi qisas-diyat harus dirumuskan ketentuan seperti jenis yang kedua, yaitu longgar, lentur, dan fleksibel. Hal ini karena adanya pendelegasian wewenang oleh Tuhan kepada negara melalui ulul amri. Oleh karenanya, padatindakpidana ta'zir, Tuhan hanya memberikan indikator-indikator (ketentuan umum) yang dapat diimplementasikan secara berbeda oleh masing-masing negara, baik jenis tindak pidananya maupun sanksinya. Di sinilah letak potensi fleksibilitas Asas Legalitas Hukum Pidana Islam tersebut.

Di samping itu, flekibilitas tersebut juga dapat dimaknai dari perspektif perumusan tindak pidana baru yang tidak mungkin diakomodasi oleh Nas karena faktor keterbatasan waktu dan cakupan dari Nas itu sendiri. Keberadaan Jarimah ta'zir yang memiliki karakteristik berbeda dengan hudud dan qisas-diyat berpotensi untuk mengakomodasi bentuk-bentuk tindak pidana baru yang muncul akibat perubahan

35 Abdul Qadir 'Audah, al-Tasyri' al-Jina'i al-Islami, hlm. 128-155; Ahsin Sakho Muhammad, et.al (eds), Ensiklopedi, hlm. 145-147; Ahmad Hanafi, Asas-Asas, hlm. 67-73.

36 Baca: Ahmad D. Hanafi, Asas-Asas Hukum Pidana Islam, hlm. 8-9. Lihat juga: M. Cherif Bassiouni (ed.), The Islamic Criminal Justice System, (New York: Oceana Publications, 1982), hlm. 166-168. 
dan kemajuan zaman. Contohnya adalah tindak kejahatan berbasis media online, tindak pidana lingkungan, tindak pidana obat-obat terlarang, extra ordinary crime, dan lain-lain.

\section{Kontribusi Asas Legalitas Hukum Pidana Islam dalam Pembaharuan Hukum Pidana di Indonesia}

Acara pidana secara umum didasarkan pada dua tujuan kembar yang pada saat yang sama bertolak belakang, yakni menjalankan proses hukum yang sepatutnya dan pengendalian efektif atas kejahatan. Proses hukum yang sepatutnya cenderung fokus pada pemberian berbagai perlindungan kepada tersangka untuk menekan kemungkinan hukuman pidana yang tidak adil atau sewenang-wenang. la juga hendak memfasilitasi penyelenggaraan peradilan yang efisien, yang memajukan objektivitas dan koherensi selama acara peradilan. Sebaliknya, kendali atas kejahatan menekankan kepentingan sosial lebih luas dalam deteksi dan pencegahan kejahatan, dan cenderung membatasi perlindungan prosedural kepada tersangka untuk menjamin penuntutan yang efisien dan penghukuman orang yang bersalah. ${ }^{37}$ Dengan kata lain, untuk mencapai keadilan hukum sangat dibutuhkan keseimbangan antara kepastian hukum dan perlindungan hak, baik pelaku, korban, maupun masyarakat.

Acara pidana Islam juga mengalami dilema ini dan hendak meraih keseimbangan yang adil antara kepentingan tersangka dan kepentingan masyarakat. Rambu-rambu prosedural tertentu kadang-kadang ditetapkan oleh al-Qur'an dan Sunnah, namun umumnya dibiarkan mengikuti kebijaksanaan penguasa. Di bawah doktrin siyasah syar'iyah, atau kebijakan berorientasi syariah, penguasa memiliki wewenang untuk mengambil langkah-langkah dan merancang prosedur yang selaras dengan maksud dan tujuan syariah dan menjamin kepentingan publik sebaik mungkin. Penyelarasan ini penting mengingat prosedur acara pidana yang dianggap cukup untuk masa lalu, belum tentu memadai untuk masyarakat yang lebih kompleks di mana kemajuan dalam berbagai bidang telah membuka peluang kejahatan dan penyalahgunaan yang lebih canggih. ${ }^{38}$

Asas Legalitas merupakan prinsip konstitusi. Teori konstitusi Islam menyatakan dengan jelas prinsip pembatasan kekuasaan negara di bawah kekuasaan hukum. Di dalam syariah tidak ada ruang untuk kekuasaan sewenang-wenang oleh seorang individu atau sekelompok orang. Dasar bagi semua putusan dan tindakan di dalam pemerintahan Islami tidak boleh berdasarkan kesewenangan individu, melainkan syariah. ${ }^{39}$ Inilah yang menjadi alasan mengapa formulasi tindak pidana (jarimah) dalam hukum Pidana Islam dirumuskan sedemikian rupa, sehingga terdapat pemisahan yang sangat tegas antara hak Tuhan (syariah) dalam hudud, hak korban dalam qisas-diyat, dan hak penguasa (negara) dalam ta'zir. Diantara beberapa hak (kepentingan) tersebut perlu adanya keseimbangan yang kuat. Sebagaimana pernyataan Topo Santoso;

\footnotetext{
37 Mohammad Hashim Kamali, Membumikan Syariah; Pergulatan Mengaktualkan Islam, (Bandung: Mizan, 2013), hlm. 235-236. Baca juga: Herbert Packer, The Limits of the Criminal Sanction, (Stanford California: Stanford University Press, 1968), hlm. 140.

38 Mohammad Hashim Kamali, Loc.Cit, hlm. 236.

39 Mohammad Hashim Kamali, Loc.Cit, hlm. 237.
} 
Hukum Islam menjalankan Asas Legalitas, tetapi juga melindungi kepentingan masyarakat. la menyeimbangkan hak-hak individu, keluarga, dan masyarakat melalui kategorisasi kejahatan dan sanksinya. ${ }^{40}$

Hak Tuhan pada dasarnya adalah representasi dari kepentingan masyarakat. Di dalamnya terdapat hak masyarakat yang harus dilindungi dan diselamatkan, sebab apabila kepentingan ini terkoyak, maka rusaklah sendisendi kehidupan yang menjadi representasi dari nilai-nilai universal sebuah masyarakat. Ketika sebuah masyarakat tidak lagi memiliki nilai-nilai dan norma-norma yang disepakati dan dijunjung tinggi maka yang berlaku adalah kepentingan individu. Hukum rimba akan diberlakukan, siapa yang kuat yang akan menang dan menjadi penguasa. Secara sederhana, ketika kehormatan dan kesucian seseorang sudah tidak lagi dianggap sebagai hak masyarakat yang oleh karenanya harus dilindungi dan dipertahankan secara bersama sebagai kepentingan bersama, maka praktek perzinaan akan merajalela dan lembaga pernikahan menjadi tidak ada gunanya. Demikian juga ketika hak milik/kepemilikan terhadap harta benda tidak dianggap sebagai hak masyarakat yang oleh karenanya harus dilindungi dan dipertahankan secara bersama sebagai kepentingan bersama, maka pencurian, perampokan, pencopetan, dan penipuan akan menjadi cara yang dibenarkan untuk mendapatkan harta benda.

Hak korban dalam tindak pidana qisas-diyat sangat jelas menggambarkan penghargaan yang tinggi terhadap prinsip keadilan. Pada kasus pembunuhan dan penganiayaan, menurut ketentuan Hukum Pidana Islam, hak untuk mewujudkan sanksi hukum sepenuhnya ada pada korban (atau walinya dalam kasus pembunuhan), setelah melalui persidangan di pengadilan dan mendapatkan putusan tetap. Maksud dari hak perwujudan sanksi ada pada korban adalah bahwa apabila korban sanggup melaksanakan proses hukuman tersebut sesuai dengan putusan pengadilan secara adil, tidak kurang dan tidak lebih, maka negara tidak boleh menghalangi. Sebaliknya, apabila korban tidak sanggup maka negara harus mengambil alih melaksanakan tugas eksekusi sebagai wakil dari pihak korban. Namun demikian, mengambil hak eksekusi maupun mewakilkan kepada negara untuk melaksanakan eksekusi hukuman bukanlah satu-satunya pilihan bagi pihak korban/walinya. Ada satu lagi pilihan yang dapat diambil oleh pihak korban yaitu memaafkan si pelaku. Apabila pihak korban memilih untuk memaafkan pelaku maka akan ada dua pilihan berikutnya, apakah pihak korban akan menuntut ganti rugi (denda) berupa diyat dengan sejumlah uang ataukah akan memaafkan sepenuhnya tanpa menuntut diyat. Inilah prinsip keadilan yang ditawarkan Hukum Pidana Islam melalui pengakuan terhadap hak-hak korban.

Hak penguasa (negara) meliputi semua kepentingan selain kepentingan Tuhan dan kepentingan korban. Hak seseorang untuk dapat hidup secara nyaman bersama keluarganya di rumah, di jalan, di tempat-tempat umum, di lingkungan yang sehat, bebas gangguan dari orang lain, menjadi kewajiban negara untuk mengaturnya. Demikian juga hak untuk dapat melaksanakan ibadah dengan aman dan khusyuk di tempat ibadah yang nyaman juga menjadi kewajiban negara untuk mewujudkannya.

40 Topo Santoso, Membumikan Hukum Pidana Islam, (Jakarta: Gema Insani Press, 2003), hlm. 12-13. 
Termasuk hak untuk mendapatkan keadilan itu sendiri dan mendapatkan perlindungan hukum, dan seterusnya. Di sini terdapat kepentingan strategis yang semestinya dimanfaatkan sebaik-baiknya oleh negara untuk melengkapi perlindungan terhadap hak masyarakat dan hak korban. Namun demikian, sebaliknya di sini juga terdapat peluang bagi penguasa yang dzalim untuk berbuat sewenang-wenang dengan memanfaatkan kekuasaan hukum yang ada pada dirinya. Jika peran strategis negara ini dapat dilaksanakan secara maksimal, maka semua kepentingan, baik sebagai bagian dari masyarakat, sebagai individu (korban) maupun sebagai warga negara akan terlindungi dengan baik, namun demikian juga sebaliknya. Menurut Nagaty Sanad, Asas Legalitas dalam Islam yang berlaku bagi tindak pidana ta'zir adalah yang paling fleksibel, dibanding dengan dua kategori sebelumnya (hudud dan qisas-diyat). ${ }^{41}$ Terpeliharanya keseimbangan antara hak masyarakat, hak korban, dan hak negara dalam interaksi yang harmonis tentu akan mendukung sistem hukum yang sehat dan adil.

Terkait perumusan RUU-KUHP, prinsip keseimbangan ini juga menjadi concern Barda Nawawi Arief. la menegaskan bahwa diperlukan pemikiran falsafati yang dapat menjadi landasan esensial atas Asas Legalitas. Pemikiran falsafati tersebut tidak lain adalah "ide keseimbangan" yang meliputi: a) keseimbangan monodualistik antara kepentingan umum/masyarakat dan kepentingan individu/perorangan; b) keseimbangan antara perlindungan kepentingan pelaku tindak pidana (ide individualisasi pidana) dan korban tindak pidana; c) keseimbangan antara unsur/faktor objektif (perbuatan/ lahiriah) dan subjektif (batiniah/sikap batin); ide daad-daader strafrecht; d) keseimbangan antara kriteria formal dan materiil; e) keseimbangan antara kepastian hukum, kelenturan/elstisitas/ fleksibilitas, dan keadilan; serta f) keseimbangan antara nilai-nilai nasional dan nilai-nilai global/ internasional/universal. ${ }^{42}$

Uraian tentang potensi besar yang dimiliki Asas Legalitas Hukum Pidana Islam dalam mewujudkan keadilan hukum secara optimal di atas, layak menjadi inspirasi bagi pembaharuan hukum pidana di Indonesia. Beberapa inspirasi yang dapat dikontribusikan antara lain: pertama, mengembalikan KUHP sebagai undang-undang yang merepresentasikan nilainilai spiritual sebagai filosofinya sebagaimana yang dikehendaki oleh sila pertama Pancasila. Sebagai hukum yang memiliki nilai-niali fundamental dan potensi spiritualitas yang tinggi karena bersumber dari nilai-nilai agama, maka Hukum Pidana Islam diharapkan akan mampu mendekatkan KUHP dan sistem perundangan Nasional dengan filosofi sila pertama Pancasila, yaitu hukum yang berketuhanan Yang Maha Esa. Ciri-ciri hukum yang berlandaskan nilainilai spiritual antara lain adalah hukum yang menjadikan moralitas dan etika sebagai bagian yang tidak terpisahkan. Orientasi yang tinggi terhadap etika dan moralitas inilah yang memposisikan hukum tidak sekedar berfungsi secara pasif, yakni sebagai instrumen yuridis menindak orang-orang yang melakukan kejahatan, namun lebih dari itu seharusnya

41 Nagaty Sanad, The Theory of Crime and Criminal Responsibilty in Islamic Law Sharia, (Chicago: Office of International Criminal Justice, 1991), hlm. 37-38.

42 Barda Nawawi Arief, Kebijakan Hukum Pidana; Perkembangan Penyusunan Konsep KUHP Baru, (Jakarta: Kencana Prenada Media Group, 2014), hlm. 103-104; Baca juga: Deni Setyo Bagus Yuherawan, Loc.Cit, hlm. 261. 
hukum mampu berfungsi secara aktif memaksa masyarakat untuk menjadi manusia yang bermoral dan berakhlak mulia sesuai agama dan keyakinannya masing-masing. Inilah mengapa Asas Legalitas Hukum Pidana Islam juga dapat menjangkau bahkan sampai pada urusan seseorang yang sangat privat, -seperti shalat, puasa, dan zakat-, yang merupakan urusan mereka dengan Tuhannya.

Kedua, Asas Legalitas adalah salah satu bagian terpenting dari undang-undang, karena di dalamnya terkandung nilai-nilai filosofis yang mendasari rumusan pasal demi pasal. Rumusan Asas Legalitas yang tepat berarti jaminan keadilan hukum. Oleh karena itu, Asas Legalitas sangat menentukan dalam membentuk sistem hukum Nasional yang kuat, efisien, responsif, dan progresif karena posisi KUHP yang sangat strategis dalam hirarki perundang-undangan Nasional, khususnya dalam rangka menghadapi perubahan dan kemajuan zaman. Terkait dengan pemikiran ini, maka ide pembaharuan yang ditawarkan adalah rumusan KUHP dengan pendekatan simpel, efisien, dan efektif tanpa mengesampingkan karakter fleksibel dan progresif. Menggunakan Hukum Pidana Islam sebagai inspirasi, rumusan KUHP nantinya sebaiknya menggunakan model klasifikasi tindak pidana yang sederhana namun komprehensif mencakup semua bentuk kejahatan, baik yang bersifat privat maupun publik. Selain itu rumusan KUHP juga harus merepresentasikan prinsip keseimbangan antara hak pelaku dan hak korban, hak individu dan hak masyarakat, serta hak negara dan hak dunia. Rumusan KUHP juga idealnya memiliki karakter progresif, yaitu memiliki daya jangkau yang luas terhadap bentuk-bentuk kejahatan baru yang diprediksi muncul pada waktu mendatang, baik sebagai jenis kejahatan baru maupun pengembangan dari jenis kejahatan yang telah ada. Dengan rumusan seperti ini diharapkan pembaharuan KUHP dapat menyelesaikan permasalahanpermasalahan yang terkait dengan Asas Legalitas sehingga mampu menjawab tantangan kemajuan zaman dan mewujudkan keadilan hukum yang sejati.

\section{Penutup}

Berdasarkan uraian di atas, maka kesimpulan dari penelitian ini adalah sebagai berikut; Pertama, Asas Legalitas Hukum Pidana Islam memiliki perbedaan karakteristik yang signifikan dibanding Asas Legalitas hukum positif pada umumnya. Secara normatif, Asas Legalitas Hukum Pidana Islam memiliki kedekatan dengan norma-norma agama karena bersumber dari Nas. Oleh karenanya, asas-asas legalitas yang dirumuskan sangat kental makna teologis dan spiritualitasnya.

Kedua, klasifikasi tindak pidana menurut Hukum Pidana Islam sebagaimana yang telah ditetapkan dalam Nas (al-Qur'an dan Hadis) menjadi hudud, qisas-diyat, dan ta'zir, merupakan perumusan yang bernilai strategis dalam membangun sistem hukum Islam yang adil. Melalui perumusan tindak pidana tersebut Hukum Pidana Islam berhasil membangun asas legalitas secara sistematis, progresif, dan memiliki tingkat fleksibilitas yang tinggi dalam penerapannya. Asas legalitas semacam inilah yang pada saatnya mampu menjalankan fungsi perundang-undangan secara lebih maksimal, tidak hanya terbatas pada fungsi perlindungan pada pelaku tindak pidana dan fungsi pembatasan terhadap kewenangan penguasa, melainkan fungsi penegakan hukum (law enforcement) yang sesungguhnya.

Ketiga, Asas Legalitas Hukum Pidana Islam memiliki kontribusi yang signifikan bagi 
pembaharuan hukum pidana di Indonesia. Asas Legalitas Hukum Pidana Islam berpotensi mewujudkan KUHP yang berasaskan filosofi sila pertama Pancasila, Ketuhanan Yang Maha Esa (kontribusi ideologis). Asas Legalitas Hukum Pidana Islam juga berpotensi mewujudkan KUHP yang memiliki rumusan tindak pidana yang sederhana namun komprehensif, serta berkarakter responsif, progresif, dan seimbang (kontribusi yuridis).

Momentum perumusan RUU-KUHP di Indonesia menjadi saat yang tepat untuk melakukan penggalian terhadap nilai-nilai maupun norma-norma hukum yang hidup dan menjadi dasar bagi perikehidupan bangsa Indonesia, salah satunya adalah norma hukum Islam. Selanjutnya, hasil penggalian tersebut perlu dilakukan kajian secara komprehensif dalam rangka merancang Asas Legalitas yang ideal bagi rumusan RUU-KUHP yang baru. Yakni Asas Legalitas yang mencerminkan kekuatan, kepastian, kemanfaatan, keseimbangan, dan menjunjung tinggi nilai-nilai keadilan yang bersumber dari budaya bangsa Indonesia sendiri.

\section{Daftar Pustaka}

\section{Buku}

Arief, Barda Nawawi, Beberapa Aspek penegakan dan Pengembangan Hukum Pidana, (Bandung: PT. Citra Aditya Bakti, 2011)

Arief, Barda Nawawi, Kebijakan Hukum Pidana; Perkembangan Penyusunan Konsep KUHP Baru, (Jakarta: Kencana Prenada Media Group, 2014)

Audah, Abdul Qadir, al-Tasyri' al-Jina'i al-Islami, (Beirut: Muassasah al-Risalah, 1994).

Bassiouni, M. Cherif (ed.), The Islamic Criminal Justice System, (New York: Oceana Publications, 1982)

Hanafi, Ahmad D., Asas-Asas Hukum Pidana Islam, (Jakarta: Bulan Bintang, 1993)
Kamali, Mohammad Hashim, Membumikan Syariah; Pergulatan Mengaktualkan Islam, (Bandung: Mizan, 2013)

Khasan, Moh, "Reformulasi Teori Hukuman Tindak Pidana Korupsi Menurut Hukum Pidana Islam", (Laporan Penelitian Individual IAIN Walisongo Semarang, 2011)

Marzuki, Peter Mahmud, Pengantar Ilmu Hukum, (Jakarta: Kencana Prenada Group, 2008).

Moeljatno, Asas-Asas Hukum Pidana, (Jakarta: Rineka Cipta, 2000)

Muhammad, Ahsin Sakho, et.al (eds), Ensiklopedi Hukum Pidana Islam, (Jakarta: PT. Kharisma IImu, 2007)

Packer, Herbert, The Limits of the Criminal Sanction, (Stanford California: Stanford University Press, 1968)

Peters, Rudolph, Crime and Punishment in Islamic Law, (Cambridge: Cambridge University Press, 2005)

Prodjodikoro, Wirjono, Asas-asas Hukum Pidana Di Indonesia, (Bandung: Refika Aditama, 2003)

Sanad, Nagaty, The Theory of Crime and Criminal Responsibilty in Islamic Law Sharia, (Chicago: Office of International Criminal Justice, 1991)

Santoso, Topo, Membumikan Hukum Pidana Islam, (Jakarta: Gema Insani Press, 2003).

Soekanto, Soerjono dan Sri Mamudji, Peranan dan Penggunaan Perpustakaan di Dalam Penelitian Hukum, (Jakarta: Pusat Dokumentasi Hukum Fakultas Hukum Universitas Indonesia, 1979)

Subekti dan Tjitrosudibyo, Kamus Hukum, (Jakarta: Pradnya Paramita, 1969)

Tongat, Dasar-Dasar Hukum Pidana Indonesia dalam Perspektif Pembaharuan, (Malang: UMM Press, 2012)

Wignjosoebroto, Soetandyo, "Ragam-Ragam Penelitian Hukum", dalam S. Irianto dan Sidharta (ed.), Metode Penelitian Hukum; Konstelasi dan Refleksi, (Jakarta: Yayasan Pustaka Obor Indonesia, 2011)

Yuherawan, Deni Setyo Bagus, Dekonstruksi Asas Legalitas Hukum Pidana; Sejarah Asas Legalitas dan gagasan Pembaharuan Filosofis Hukum Pidana, (Malang: Setara Press, 2014)

\section{Makalah/Artikel/Laporan/Hasil Penelitian}

Rahayu, Sri, "Implikasi Asas Legalitas dalam Penegakan Hukum dan Keadilan", Jurnal Inovatif Vol. VII No. 3, (2014) 
Suartha, I Dewa Made, "Pergeseran Asas Legalitas Formal Ke Formal dan Material dalam Pembaharuan Hukum Pidana Nasional", Jurnal Yustisia 19, (2015)

WIgnyosoebroto, Soetandyo, "Nenek Minah Tak Curi Cokelat", Opini Kompas, 15 Februari 2010; Kasus "biji randu"

\section{Internet}

h t t p : / / regional.kom pas.com / $\mathrm{read} / 2009 / 11 / 19 / 07410723 /$ duh....tiga.buah. kakao.menyeret.minah.ke.meja.hijau. (diakses 1 April 2017) h t t p://nasional.kom pas.com / $\mathrm{read} / 2009 / 12 / 10 / 10563340 /$ Hukum.di.Balik. Sekarung.Buah.Randu. (diakses 1 April 2017)

h t t p : / / n a s i o a l. kom pas . com / $\mathrm{read} / 2012 / 01 / 06 / 09445281 /$ Kejamnya. Keadilan.Sandal.Jepit. (diakses 1 April 2017)

h t t p : / / nasion a . kom pas.com / $\mathrm{read} / 2009 / 11 / 30 / 23470786 / \mathrm{semangka}$. darwati.antar.kholil.masuk.penjara. (diakses 1 April 2017)

h t t p : / / region a I. kom pas.com / $\mathrm{read} / 2015 / 04 / 24 / 17200701 /$ Asyani.Teriakkan. Ketidakadilan. (diakses 1 April 2017) 